William Proios

USA

\title{
RE-THINKING THE HUMAN CONDITION IN THE AGE OF MODERNITY
}

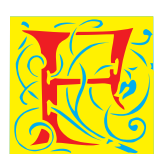

rom where does the anxious suspicion arise that the biblical eschatology of last things and end times is rapidly approaching? Apocalypse originates in the ancient Greek word apocalypsis, which means to uncover what you could not see before-to reveal. The biblical use of the word "apocalypse" means that which is revealed by divine intervention. For purposes of this paper I will adhere to the ancient Greek meaning which can be stated as simply taking note of that which has been overlooked.

One thing that has not been overlooked is how European history is riddled with violence over religious beliefs. The modern response has been to diminish religious relevance. But that was followed by unparalleled nationalistic violence in the $20^{\text {th }}$ century. Today, $21^{\text {st }}$ Century Europe remains embroiled in religious conflicts despite its best efforts to avoid them. In the hope of pursuing a more promising path to peaceful existence, I offer some overlooked biblical and secular observations about the human condition.

Modernity originates with Western culture; and that culture is overwritten with Christendom. To re-think the human condition begins with re-thinking the biblical. But to that there is resistance. Europe has turned Christendom into a relic. It has turned away from entanglement in conflicts over dogma and moral certainty by embracing the materiality of an endless progress regulated by the modern equivalent to spirituality found in an enforcing of liberal Democracy.

The belief in the endless amelioration of human conditions that is imbedded in the word "progress" has no last things or end time. Instead, progress is about endless change. Its relationship to eschatology seems clear enough: the eschatological tribute to last things has given rise to the modern answer of endless offerings through progress. But progress presupposes knowledge of human 
needs as well as what it is to be human. If human beings were instinctual then progress would conform to satisfying the instinct. But we are not instinctual. Instinct is an existence in which freewill and choice are overridden by subservience to a predetermination. In Christian eschatology there can be no belief in human instinct because, without freewill, there would be no freedom to accept salvation. Biblically, sin or salvation is a choice. Hence, for freewill to be free it must be at minimum, sin or salvation. Biblically, human beings bring a multi-directional intentionality to every condition. Being without an instinct is essential to the relationship between eschatology and progress. Unlike all the creatures of the earth, being human, biblically represented in the generic as man, is the creature without boundaries, appearing to be seemingly limitless. That is where progress compensates for eschatology by representing man without last things or an end time. Progress is the logical and reasonable representation of a future with unlimited possibility: antidote to the eschatological.

But there is a problem with being non-instinctual. Being unbound to instinct, man needs to judge: to make choices and decisions. And judgment in the West is historically associated with the biblical. Judgment is the power to both make [to judge] and to receive judgment [to be judged]. There is no predetermined right or wrong/good or bad for the creature lacking instinct; but every choice involves those judgments. The significance of this is that human judgment originates in having a need-a need to judge: where instinct resides in all other creatures, need occupies man.

Instinct, that pre-determiner of choice-less action, frees all other creatures from responsibility for their actions. Man lacks that creaturely freedom. This places man squarely in the position of being condemned by having the need to judge. But man is not simply the product of conditions or environment, man is both the sum of his judgments and greater than that sum because of freewill. Thus man is not bound to the past as prologue.

\section{Logic, reason, and nature}

Born into freedom, in a world limited by the boundaries of nature's methodological systems of selection and evolution, is the paradox of conditions confronting mankind. In answer, the human condition manifests itself by producing morality; by imitating the boundedness found in nature. Forging the constructs of moral boundaries to oppose a boundless origin in freewill has 
always plagued mankind. The possibility for endless progress versus the eschatological boundedness recycles the ancient dilemma in which the limitless are confronted with the limited. In the response to the conflict between freewill and moral boundaries there arises a dependence upon logic and reason.

From infancy, having need can be understood to be the cause of the infant's fear of annihilation: every human need, lacking instinctual directedness, becomes the possibility of an ending; a potential fall into the abyss of personal extinction-death. The human response to that fear is universal-mastery. From toilet training to language, man gains mastery as attempted compensation for having need. Not just any need, but for originating in need, as in original need. Human mastery is not just the desperate attempt to conquer need itself, it is also the attempt to gain compensation for having need in the first place-for being without a creaturely instinct.

The absence of instinct becomes the need to make and receive judgment: to judge and be judged. It is in this context that the human infant experiences hunger as an injustice because it is experienced as a need - as a threat. Thus, the injustice of needing to make and receive judgment originates at the outset of birth.

After infancy, childhood takes hold by responding to need through the literalism of logic. Human logic is derivative of nature. Charles Darwin discovered the origins of that logic in his discovery of natural selection: the completely literal logic of process in nature. The discovery ignored how man imitates nature in a desperate attempt to escape the complex demands of freewill. But that is not man's only retreat from the reality of conditions.

After the literalness of logic comes discovery of the symbolism of reason in nature. Darwin describes it in nature as evolution. But where logic acts as the sighting of the trees, reason is the proclaiming of a forest. But human reason is only a foil against the uncertainties of living with freewill. Reasoning is man attempting to imitate the evolutionary formations found in nature. But because man has freewill none of this is natural to him. It remains his need to make and receive judgments - to judge and be judged. All of which, from need driving man to mastery for compensation for having need, and logic and reason handicapping man with the predictable limitations of nature, are prevalent in both the East and the West.

Both East and West are hobbled by the need for the pure literalism of logic (originating in natural selection) as an excuse for man's choices, while using reason to cripple man with a need for the pure symbolism of symbolic immortality (originating in nature's evolution). 
Logic manifests itself in the complete literalism of the need for individual choices. Reason is manifested in the pure symbolism of symbolic immortality expressed through culture or revolution. Like Rome holding together an empire over logically divergent others, Tito held together Yugoslavia within a tent of reason until the logic of individualism—religious and ethnic, propelled its dissolution.

Historically, reason and logic have been used to civilize man. There is the open space of the agora in which political man took first steps. This was followed by religious man obtaining the dominance of his mastery in the moral management of the home through placement in the church/synagogue. The third one is psychological man who learned to institute a therapeutic morality by securing a process for returning to individual justification. All are causal of human neediness manifesting a mastery to compensate for having need in the first place. Conflating them into economy, as Karl Marx did, missed the human point.

The effect is to shorten the distance between individual and communal mastery with totalization: promising to promote peace by therapeutically homogenizing humankind with manageable interiors for conforming to manageable households derived from management of public space. For which liberal Democracy has become instrumental by elevating compensation to a just reward. But all those spaces are man-made, not ontologically human.

\section{Gospel censure of all morals and every morality}

Unlike the East, Western culture is overwritten with a Judeo-Christian story. In the Christian portion of the story there is the censure of all morals and every morality in the Gospel. But observing that the Gospel censures all morals and every morality does not easily come to mind. There are those who believe that the commandment to love our neighbor was a moral commandment. But that can be shown to be a mistaken assumption.

We are told in the Gospel that the most important commandment is to love God with all one's heart, mind, and soul. The second most important commandment is to love our neighbor as ourselves. We are further informed to love God, not worship Him - the Sabbath made for man not man for the Sabbath. In telling us to love our neighbor we are warned against falling into the narcissism of self-worship by being told to love our enemies. Approaching God with love and approaching others with love becomes the fulfillment of all 
commandments. The boundless approach of love serves seamlessly where relationships and associations can only fail.

Paul addresses the significance of love. Summed-up-love is immeasurable and un-possessing. Paul also addresses the question of following human logic and reason. He tells us to give up our childlike ways. He can say this because before there is human logic or reason there is love. Infants are born with love. They show love in the faith by which they reach out without knowing. Faith is the action of love. Faith is not blind, it simply frees us to see and hear without the need to judge. But out of infancy comes the child: where there was faith, trust enters. The unbounded existence in the womb had no need of connections or associations or relationships. Like freewill, the primal experience of being human is the absence of boundaries: freedom from need. The dawning of the end of boundless existence, when being human becomes being manmade, becomes the need, as Sigmund Freud discovered, to make the connections of relationships from the experience of associations. It is when we go from being in the world to being of the world.

The Gospel censure of morals and morality raises the question of human need. It does so by addressing our originating in a need to approach God with love-the easy yoke and light burden. The Gospel Ministry is filled with healing and granting through unbound faith in God. The miracles act to vanquish human need as promissory of the coming of a new heaven upon a new earth. The Gospel condemnations of the immoral and amoral are also evidence of the censure. Because, in presenting a censure of morals and morality, it becomes incumbent to establish that the censure is not an invitation to immorality. The censure is always a call to righteousness - to the eternal.

Because of man's freewill, the Gospel uses parables to illustrate the censure. Parables serve to encourage us toward the path of righteousness by urging us away from the path of valuation found in the measurements and possessions of morality. The parables insistently challenge moral norms with seeming paradoxes of inconsistency: the field hand beginning near workday's end receiving the same as the one who began at start of day; the prodigal son being equally received in his father's house as the son who never left; or, how the last may be as the first and the first as the last. The parables serve to censure the measurements of morality without judging them, without condemning them. The Gospel censure is the gentlest of urgings.

The Gospel is finalized with betrayal and sacrifice leading to crucifixion followed by resurrection. Many had believed that it was sacrifice that was the 
example of the prophesized Messiah in the Old Testament. But, in the resurrection, the power of betrayal and sacrifice prove to be only temporal-like morals. The many were only partly correct, the example was of sacrifice, but of sacrifice having no lasting power or authority over the righteous.

After the ministry of ending need with faith in loving God, the crucifixion and resurrection proved to be for fulfilling the rendering unto Caesar that which is Caesar's. Caesar exemplifies the human way: betrayal—crossing the Rubicon with his army, and sacrifice-assassinating Caesar to save the Republic.

Historical or Augustinian Christendom attaches a morality of faith (a loyalty/betrayal order) to the Gospel. Attaching the profane to the biblically sacred originates first in the Old Testament. The primary example is the one in which being divinely chosen becomes the defendable boundaries of a moral condition: first, the nation of Israel, then Judea, culminating in Jewish culture. Augustinian Christendom attempts to imitate that example. Except that, in the Old Testament, the offerings of moral possibilities are presented in stark contrast to prophetic calls to righteousness. But Augustinian Christendom does not offer moral possibilities in contrast to righteousness. Instead, attaching their morals to the Gospel, they usurp the Gospel censure to condemn all other morals and every other morality-including the Judaic. And, in their imitation, they take pride in claiming the mantel of Christian nation or Christian culture while studiously ignoring the conflict in the Old Testament juxtaposition of moral possibilities versus righteousness. In that juxtaposition resides the Judaic struggle over the conflict between obedience to the strictures of moral laws, and serving the fulfillment of prophetic calls to righteousness. That cultural and individual internal struggle over conflict can become embroiled in needing moral defenses against the intrusions and probing's of other moralities and sanctities.

Genesis provides another example of the profane being attached to the sacred for divine purposes. A record of the Hebraic family is precisely given: especially in the begetting, but also in detailed accounts of the secular activities of the Hebraic families. They are preserved in accord with the will of God. But honoring the Hebraic with sacred memorialization can also be seen as preparation for the Hebraic to honor His Son as He honored the sons of the Hebraic. On presenting this observation to a Christian theologian I was immediately rebuked, with the indignation of "What about our freewill?" The very possibility was felt to be an unfair pre-determination that slandered man's freewill: as if all the efforts of men had 
been pre-judged to failure. The Christian theologian is not alone in rejecting the Old Testament pre-determination of the Son as Messiah. The Judaic and Islamic also each have long held grounds for rejecting it as slander. But here is the crucial biblical point, and essential eschatological reference. Man has always been free to be freed from sin, but without preparation for the Son, then man is burdened with the need to bring about his own salvation. And God, knowing man, knows that man does not respond well to need. The biblical preparation for the Son lifted the burden of need from man, it freed man.

Despite the Gospel censure it has become common for individuals, communities, societies, and a culture to use the Gospel for claiming a moral high ground. It has enabled them to wield a power beyond their means or reckoning. But it is trespass, and trespass promotes violence. Falsely authorizing the Gospel for moral purposes misrepresents the censure as the judgment of a condemnation. The usurpation promotes a ceaseless aggression against all other moralities: appearing as culture or religious wars by turning man against man.

So long as the Christianized usurp the Gospel message by avoiding and ignoring the Gospel censure they will continue to incite anti-Semitism. Usurping the Gospel for moral purposes produces anti-Semitism. Judaism is targeted by Christianized morality's practiced avoidance of the Gospel censure of all morals and every morality. Instituting a moral Christendom corrupts the Gospel message with hatred and jealousy for all other moralities, beginning with the Judaic. Ultimately usurpers turn to violence because they can never defeat Judaism on moral grounds. The pogroms, the Inquisition, and the Holocaust, were all signatory to that stalemate.

From Old to New Testament each suffers the loss of its own biblical delivery into salvation with resigned acceptance of moral reign over the very promise of righteousness that censures all morals and every morality.

Enigmatically, the Gospel way of example has presence without the conditionality of any moral equivalence. Paradoxically, the juxtaposition of moral conditionality beside prophetic righteousness appears unfinished. The Gospel enigma and the Judaic paradox are at the troubled heart of modernity's condition in which the denial of "last things" is fraught with attraction to the completion of judgment. 
Biblically, the word judgment means condemnation. Righteousness is the call to abjure from judging, to abjure from condemning (abjuring from an eye for an eye): only one without sin can remain unscathed by that double edged sword-that making and receiving of judgments. 